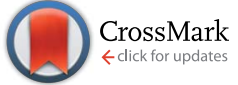

Cite this: RSC Adv., 2016, 6, 3487

\title{
Bio-kinetics evaluation and batch modeling of the anammox mixed culture in UASB and EGSB reactors: batch performance comparison and kinetic model assessment
}

\begin{abstract}
Qigui Niu, ${ }^{a}$ Shilong He, ${ }^{\text {ab }}$ Yanlong Zhang, ${ }^{a}$ Yu Zhang, ${ }^{c}$ Min Yang ${ }^{c}$ and Yu-You Li ${ }^{\star a}$
To predict the performance and evaluate the optimized process operation, a number of kinetic models were conducted in batch experiments for UASB-anammox biomass and EGSB-anammox biomass. Following a time series with substrate variations, the reaction of the mixed culture was separated into three phases: the anammox reaction, denitrification and cell lysis. Among the six selected kinetic models, the Hanlev and Luong models were found to be the most appropriate, with a prospected $r_{\max }$ of 0.28 , $0.30 \mathrm{gN} \mathrm{gVSS}^{-1} \mathrm{~d}^{-1}$, a $\mathrm{K}_{\mathrm{s}}$ of $53.38,52.52 \mathrm{mg} \mathrm{NH}_{4}{ }^{+}-\mathrm{N} \mathrm{L}^{-1}$ and inhibition coefficient of 900 and $928 \mathrm{mg} \mathrm{N}$ $L^{-1}$, respectively. Significant differences were found in the simulated specific anammox activity (SAA) in the two reactors following longitudinal distribution. The EGSB-anammox biomass had the highest $r_{\max }$ of $0.30 \mathrm{gN} \mathrm{gVSS}^{-1} \mathrm{~d}^{-1}$, and a $K_{\mathrm{s}}$ of $53.38 \mathrm{mg} \mathrm{NH}_{4}{ }^{+}-\mathrm{N} \mathrm{L}^{-1}\left(123.84 \mathrm{mg} \mathrm{TN} \mathrm{L}^{-1}\right.$ ), both validated in the models and experimentally. In contrast, a large variation was found in the UASB-anammox biomass, from 0.1 to $0.6 \mathrm{gN} \mathrm{gVSS}^{-1} \mathrm{~d}^{-1}$ from the top to the bottom of the reactor, and the removal efficiency of the whole system was lower. It was also found that a second feeding tended to increase the SAA for higher purity anammox biomass.
\end{abstract}

Received 24th July 2015

Accepted 7th December 2015

DOI: $10.1039 /$ c5ra14648h

www.rsc.org/advances knowledge of the kinetics of the anammox biomass is most important. This knowledge will assist in the process design and for establishing the operation conditions.

Most of the anammox processes utilize a mixed culture with functional communities predominated by anammox bacteria. In the enrichment of anammox, there are four consecutive phases of anammox enrichment: cell lysis phase, the lag phase, the activity elevation phase and the stationary phase. With the seed of various functional groups in the reactor, the competition between the bacteria is accommodated. Denitrification is continuously weakened in the stationary phase, with anammox gradually becoming the dominant reaction. The anammox performance of the reactors was significantly enhanced in the activity elevation phase. Nevertheless, heterotrophic denitrification still predominant throughout the start-up course due to the extremely low growth rate of anammox bacteria. One inoculation strategy, where nitration sludge is the main inoculum and is co-mixed with anaerobic granular sludge, has been shown to contribute to a relatively shorter start-up time and better reactor performance. There are three major bioprocesses in the anammox reaction which have been quantified with regard to the relevant reactions and microbial growth aspects: the anammox reaction, denitrification and cell lysis. ${ }^{3}$ When a limited amount of substrate is in the vial, denitrification and cell lysis are the two leading reactions. Anammox activity is negligible once the anammox cell decays, and cell lysis becomes
${ }^{a}$ Department of Civil and Environmental Engineering, Graduate School of Engineering, Tohoku University, 6-6-06 Aza-Aoba, Aramaki, Aoba-ku, Sendai, Miyagi 980-8579, Japan. E-mail: gyokuyu.ri.a5@tohoku.ac.jp; Fax: +81 227957465; Tel: +81 227957464 ${ }^{b}$ School of Environment and Spatial Informatics, China University of Mining \& Technology, Xuzhou 221116, China

${ }^{c}$ State Key Laboratory of Environmental Aquatic Chemistry, Research Center for EcoEnvironmental Sciences, Chinese Academy of Sciences, P.O. Box 2871, Beijing 100085, China 
predominant in the vial. The density of the anammox cell gradually lessens as the denitrifying cell thrives in the presence of $\mathrm{NO}_{3}-\mathrm{N}$ and organic matter.

The kinetics of the anammox reaction is a theoretical guide to the potential capability of the anammox bacteria. These bacteria include $K_{\mathrm{s}}$ and the $K_{\mathrm{i}}$, both of which are important for the bacteria growth and the engineering application. Since substrate inhibition has been shown to be a major obstacle for the efficient and stable operation of the anammox process, ${ }^{4}$ techniques to ensure high treatment performance and stability in the anammox process are being actively investigated. Over the past twenty years, many researchers have reported on techniques to optimize the parameters of the anammox process, focusing on the following key issues: substrate inhibition and the effect of temperature, organic matter and salinity on the system. While it has been reported that a simultaneous rise in the concentrations of the substrate $\left(\mathrm{NH}_{4}{ }^{+}-\mathrm{N} / \mathrm{NO}_{2}{ }^{-}-\mathrm{N}=\right.$ $1: 1.32$ ) results in the suppression of anammox activity when the nitrite level of the influent is higher than $280 \mathrm{mg} \mathrm{N} \mathrm{L}^{-1,5}$ other reports indicate that ammonium levels as high as 1000 mg $\mathrm{N} \mathrm{L}^{-1}$ did not inhibit anammox processes. ${ }^{2}$

The Specific Anammox Activity (SAA) has been demonstrated to be a very useful tool in assessing the behavior of the anammox biomass under different conditions with and without the inhibitors. Therefore, SAA tests were carried out to shed light on the anammox reaction, which can be used as an indicator for the management of operating conditions. Most of the research has focused on the total nitrogen removal, with only a few investigations focused on the maximum $\mathrm{NH}_{4}{ }^{+}-\mathrm{N}$ and $\mathrm{NO}_{2}{ }^{-}-\mathrm{N}$ consumption rate and $\mathrm{NO}_{3}{ }^{-}-\mathrm{N}$ production in the batch experiment. In this paper, 6 usable kinetic models that quantitatively describes the substrate inhibition of anammox were used to simulate the anammox reaction (Haldane model, Edwards model, Luong model, Han-levenspiel, Monod and Aiba model). All of the simulation resluts were compared to assess the kinetic models. In addition, the characterization and variation of $\mathrm{N}_{2}$ gas production and the related individual nitrogen in the reactors were also investigated.

\section{Material and methods}

\section{Characteristics of anammox sludge}

The characteristics of the two kinds of sludge taken from the long term operated UASB and EGSB reactor are shown in Table 1.

\section{Synthetic wastewater}

The influent ratio of substrate $\mathrm{NO}_{2}{ }^{-}-\mathrm{N}$ to $\mathrm{NH}_{4}{ }^{+}-\mathrm{N}$ was kept at 1.32 : 1 using $\left(\mathrm{NH}_{4}\right)_{2} \mathrm{SO}_{4}$ and $\mathrm{NaNO}_{2}$. The composition of the mineral medium was as follows: $0.57 \mathrm{~g} \mathrm{~L}^{-1}$ of $\mathrm{KCl}, 0.688 \mathrm{~g} \mathrm{~L}^{-1}$ of $\mathrm{NaHCO}_{3}, 300 \mathrm{mg} \mathrm{L}{ }^{-1}$ of $\mathrm{CaCl}_{2} \cdot 2 \mathrm{H}_{2} \mathrm{O}, 50 \mathrm{mg} \mathrm{L}{ }^{-1}$ of $\mathrm{KH}_{2} \mathrm{PO}_{4}, 200$ $\mathrm{mg} \mathrm{L}{ }^{-1}$ of $\mathrm{MgSO}_{4} \cdot 7 \mathrm{H}_{2} \mathrm{O}$. Trace element I included $\mathrm{FeSO}_{4} \cdot 7 \mathrm{H}_{2} \mathrm{O}$

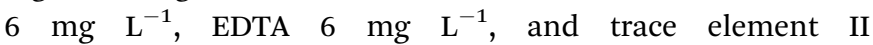
included $\mathrm{ZnSO}_{4} \cdot 7 \mathrm{H}_{2} \mathrm{O} 0.538 \mathrm{mg} \mathrm{L}{ }^{-1}, \mathrm{CoCl}_{2} \cdot 6 \mathrm{H}_{2} \mathrm{O} 0.3 \mathrm{mg} \mathrm{L}{ }^{-1}$, $\mathrm{MnCl}_{2} \cdot 4 \mathrm{H}_{2} \mathrm{O} 1.125 \mathrm{mg} \mathrm{L}{ }^{-1}, \mathrm{CuSO}_{4} \cdot 5 \mathrm{H}_{2} \mathrm{O} 0.313 \mathrm{mg} \mathrm{L}{ }^{-1}, \mathrm{H}_{3} \mathrm{BO}_{3}$ $0.018 \mathrm{mg} \mathrm{L}^{-1}, \mathrm{NiCl}_{2} \cdot 6 \mathrm{H}_{2} \mathrm{O} 0.238 \mathrm{mg} \mathrm{L}{ }^{-1}, \mathrm{Na}_{2} \mathrm{SeO}_{4} \cdot 10 \mathrm{H}_{2} \mathrm{O} 0.123$ $\mathrm{mg} \mathrm{L} \mathrm{L}^{-1},\left(\mathrm{NH}_{4}\right)_{6} \mathrm{Mo}_{7} \mathrm{O}_{24} \cdot 4 \mathrm{H}_{2} \mathrm{O} 0.275 \mathrm{mg} \mathrm{L}{ }^{-1}, \mathrm{Na}_{2} \mathrm{WO}_{4} \cdot 2 \mathrm{H}_{2} \mathrm{O}$ $0.664 \mathrm{mg} \mathrm{L}^{-1} \cdot{ }^{6-8}$

\section{Procedure of batch tests and nitrogen degradation study}

The assays were performed in vials. The total volume of each vial was $120 \mathrm{~mL}$ (with an effective volume of $100 \mathrm{~mL}$ ), and all of the vials were closed with rubber plug and then covered by aluminum cap capable of withstanding approximately 1.5 bars of pressure. The anammox reaction was studied over a concentration range of $50-400 \mathrm{mg} \mathrm{NH}_{4}{ }^{+}-\mathrm{N} \mathrm{L}^{-1}$ (TN: total nitrogen 116-928 $\mathrm{mg} \mathrm{L}^{-1}$ ) with 50, 100, 200, 300 and $400 \mathrm{mg}$ $\mathrm{NH}_{4}{ }^{+}-\mathrm{N} \mathrm{L}^{-1}$ in different vials. An $\mathrm{NaHCO}_{3}$ buffer was used to keep the initial $\mathrm{pH}$ at around 7.5. Each vial was inoculated with $5 \mathrm{~g}$ anammox biomass enriched in the reactors with the dominant anammox species Ca. Kuenenia stuttgartiensis. The anammox biomass was washed and re-suspended in a phosphate buffer $\left(0.14 \mathrm{~g} \mathrm{~L}^{-1} \mathrm{KH}_{2} \mathrm{PO}_{4}\right.$ and $\left.0.75 \mathrm{~g} \mathrm{~L}^{-1} \mathrm{~K}_{2} \mathrm{HPO}_{4}\right)$ to

Table 1 Characteristics of UASB-anammox biomass and EGSB-anammox biomass

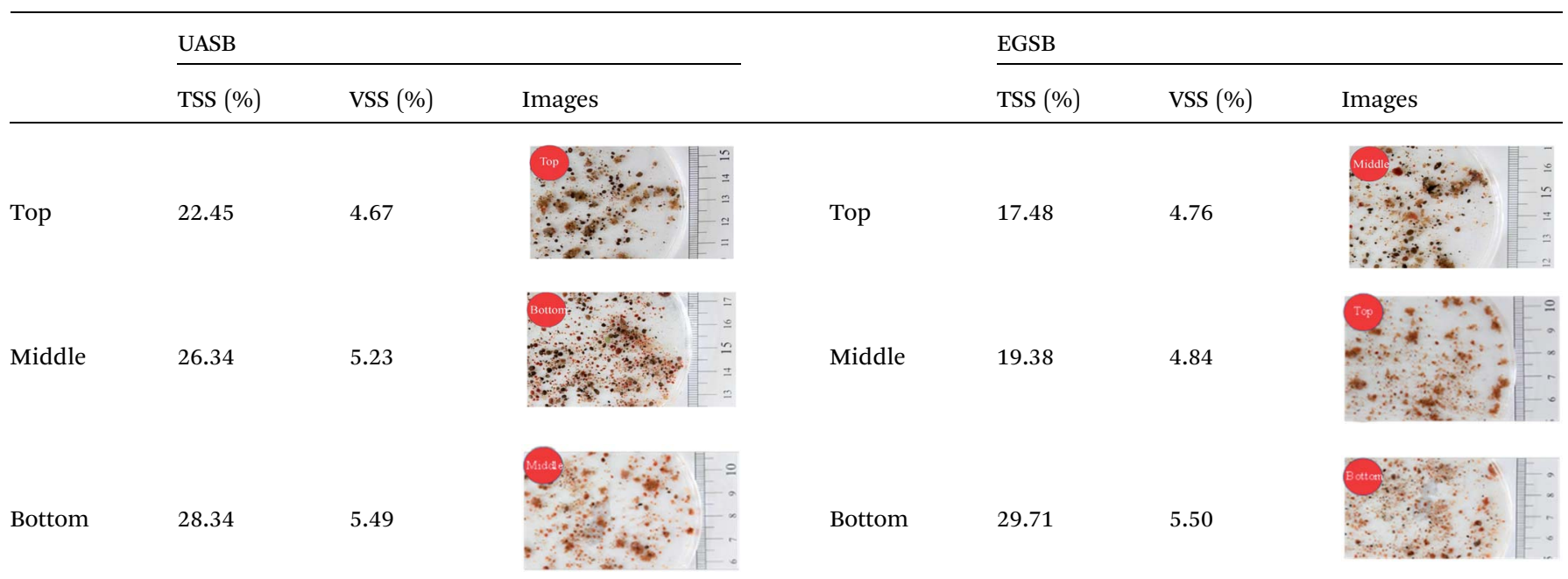


remove the residual substrate. The headspace and liquid phase were gasified with pure nitrogen gas to remove the oxygen. The vials were placed in a thermostatic water bath shaker, shaken at $120 \mathrm{rpm}$ and kept at $35{ }^{\circ} \mathrm{C}$ as in the reactor. After the addition of the $\left(\mathrm{NH}_{4}\right)_{2} \mathrm{SO}_{4}$ and $\mathrm{NaNO}_{2}$ substrates, the pressure balance was determined after warming the vial for 5 minutes to ensure the pressure of the inner vial was equal to the atmospheric pressure. The production of $\mathrm{N}_{2}$ gas was tracked by measuring the overpressure in the headspace with a lubricated syringe, depending on the anammox activity in each vial.

In order to test the accuracy of the experiment, two feedings were conducted. A first run of assays was carried out to assess the accuracy of the method to rapidly estimate the specific anammox activity. In this run, activity tests under different initial concentrations of substrates with an initial $5 \mathrm{~g}$ wet biomass were performed to evaluate the consumption rate in the liquid and the gas production rate. Based on the total nitrogen gas production (calculated by the theoretical feeding substrate concentration) and individual nitrogen concentration analysis, the kinetics of the SAA were tested with more than 6 times sampling. Each sample of $1 \mathrm{~mL}$ of liquid was taken from the vial and backfill with pure nitrogen gas simultaneously to maintain the appropriate pressure stabilization. The liquid samples were firstly passed through a $0.45 \mu \mathrm{m}$ filter and analyzed immediately or stored temporarily at $4{ }^{\circ} \mathrm{C}$. A second run was conducted to verify the sensitivity of the biomass activity. The total amount of $\mathrm{N}_{2}$ gas produced was calculated from the sampling gas value taken with a gas syringe from the headspace of each vial using the ideal gas law equation. The total amount of nitrogen removed from the liquid phase was investigated by measuring the ammonium, nitrite and nitrate concentrations. The amount of ammonium and nitrite consumed and the amount of nitrate produced were calculated based on the concentrations in the vials.

\section{Maximum specific anammox activity}

The $\mathrm{N}_{2}$ gas production rate at $35^{\circ} \mathrm{C}$ was calculated from the maximum slope of the nitrogen accumulation curve. The SAA is calculated from the $\mathrm{N}_{2}$ gas production rate divided by the biomass concentration in the vial $X\left(\mathrm{~g} \mathrm{VSS} \mathrm{L}^{-1}\right)$. The maximum specific anammox activity (MSAA) was estimated from the maximum slope of the curve indicated by the decrease of ammonium and biomass concentrations in the vials with the passage of time: ${ }^{9}$

$$
\begin{aligned}
\operatorname{MSAA}(\mathrm{g} N \text { per } & \mathrm{V} \operatorname{VSS} \text { per } \mathrm{d}) \\
& =\frac{\mathrm{dN}_{2} / \mathrm{d} t}{X V_{\mathrm{L}}} 28 \mathrm{~g} \mathrm{~N} \text { per mol } \mathrm{N}_{2} 1440 \text { min per } \mathrm{d}
\end{aligned}
$$

where $V_{\mathrm{L}}$ is the volume of the liquid phase (L). Dividing this value by the known amount of biomass present in the bottle at the beginning of the test, the maximum specific anammox activity was calculated and expressed as $\mathrm{gN}\left(\mathrm{N}_{2}\right) \mathrm{gVSS}^{-1} \mathrm{~d}^{-1}$. The modified Boltzmann model was used to stimulate the slip of the $\left(K_{\max }=\mathrm{dN}_{2} / \mathrm{d} t\right)$ :

$$
V=V_{\max } \exp \left[-\exp \left(\frac{K_{\max }}{V_{\max }} e(\lambda-t)+1\right)\right]
$$

The percentage of activity maintained when inhibitory compounds were tested was calculated as follows:

$$
\mathrm{SAA}(\%)=\frac{\mathrm{SAA}}{\mathrm{MSAA}} \times 100
$$

where MSAA is the maximum specific activity and SAA is the specific activity of the vial tests under different substrate concentrations.

\section{Analyses and calculations}

Chemical analysis. The concentration of ammonium, nitrite and nitrate were analyzed by ion chromatography (DIONEX, DX120). Daily records of $\mathrm{pH}$ and gas production were kept: the $\mathrm{pH}$ was determined by a $\mathrm{pH}$ meter (TOA, HM-30V), and gas production was determined by a wet gas flow meter and the produced gas was analyzed by gas chromatography (Shimadzu, C-R8A). TN was calculated as the sum of the nitrite, nitrate and ammonium. The consumption of ammonium (mg $\left.\mathrm{L}^{-1} \mathrm{~min}^{-1}\right)$ and nitrite was calculated as follows: ${ }^{10}$

$$
\begin{aligned}
\Delta \mathrm{NH}_{4}{ }^{+}-\mathrm{N} & \\
& =\left(\frac{\left(V_{t i}-i\right) \times C\left[\mathrm{NH}_{4}^{+}-\mathrm{N}\right]_{t}-\left(V_{t i}\right)-C\left[\mathrm{NH}_{4}^{+}-\mathrm{N}\right]_{t+1}}{\Delta t}\right)
\end{aligned}
$$

$$
\begin{aligned}
\Delta \mathrm{NO}_{2}{ }^{-}-\mathrm{N} & \\
& =\left(\frac{\left(V_{t i}-i\right) \times C\left[\mathrm{NO}_{2}{ }^{-}-\mathrm{N}\right]_{t}-\left(V_{t i}\right)-C\left[\mathrm{NO}_{2}{ }^{-}-\mathrm{N}\right]_{t+1}}{\Delta t}\right)
\end{aligned}
$$

The consumption/production of nitrate $\left(\mathrm{mg} \mathrm{L}^{-1} \mathrm{~min}\right)$ was calculated by the following equation:

$$
\begin{aligned}
\Delta \mathrm{NO}_{3}{ }^{-}-\mathrm{N} & \\
& =\left(\frac{\left(V_{t i}-i\right) \times C\left[\mathrm{NO}_{3}{ }^{-}-\mathrm{N}\right]_{t}-\left(V_{t i}\right)-C\left[\mathrm{NO}_{3}{ }^{-}-\mathrm{N}\right]_{t+1}}{\Delta t}\right)
\end{aligned}
$$

Kinetic analysis. The substrate degradation rates and biogas production ratio were modeled as a function of substrate concentration on the anammox reaction. Since the kinetic experiments were conducted over a wide range of substrate concentrations, several kinetic models were conducted and compared for SAA simulation. The models are illustrated below, from eqn (7)-(12):

Eqn $(7)^{11}$

$$
\text { Haldane model }: r=\frac{S \times r_{\max }}{S+K_{\mathrm{s}}+S^{2} / K_{\mathrm{IH}}}
$$


(a) Bottom of Reactor
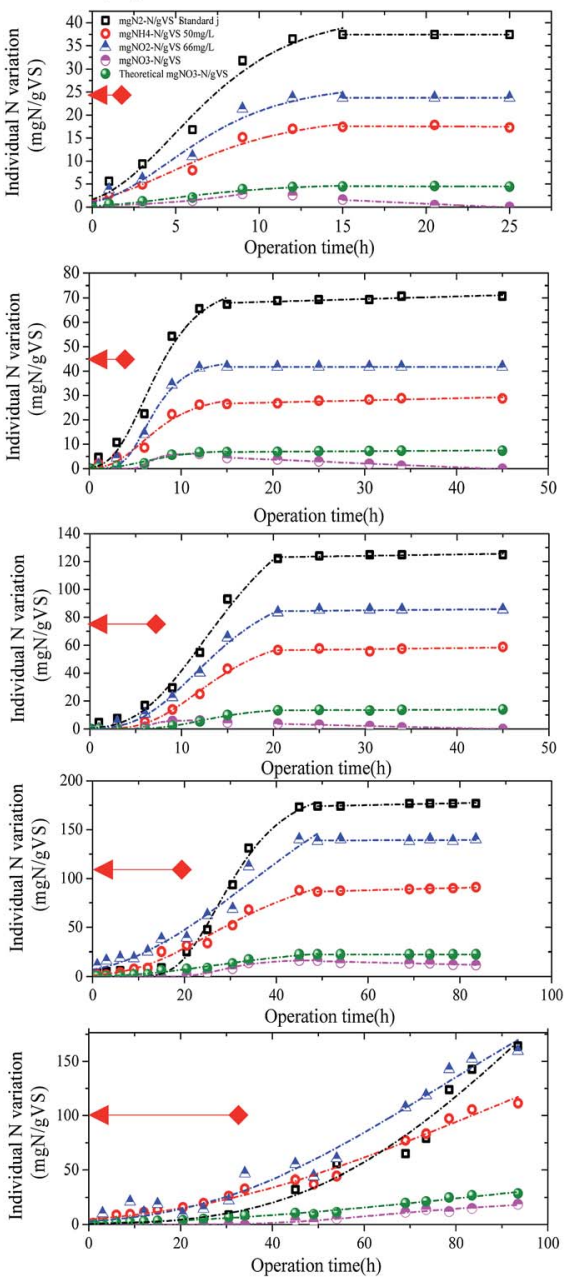

(b) Middle of Reactor
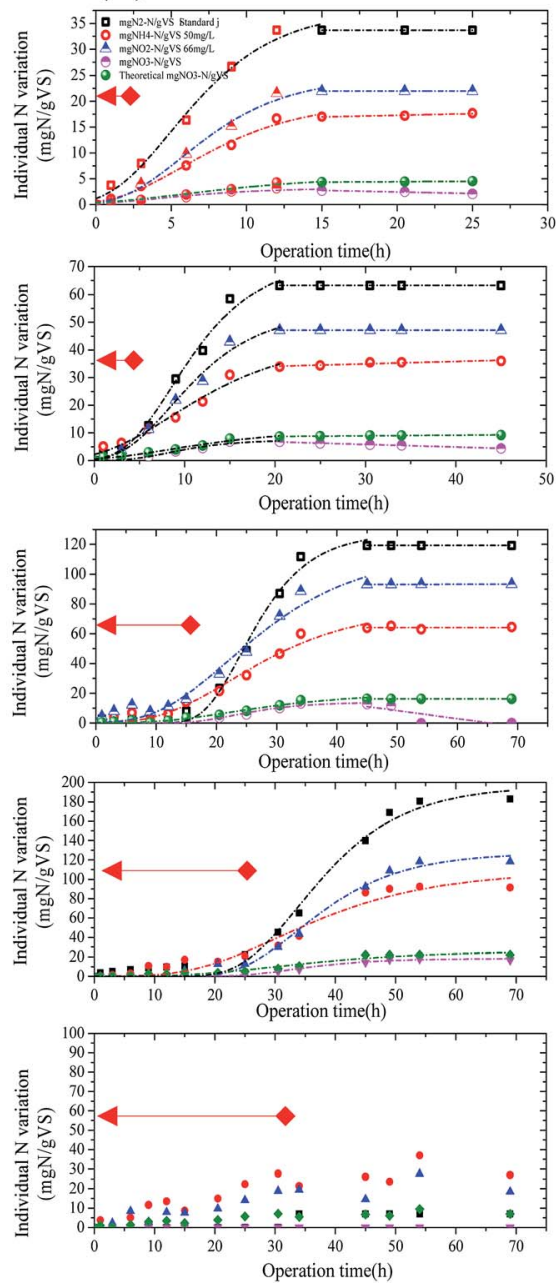

(c) Top of Reactor
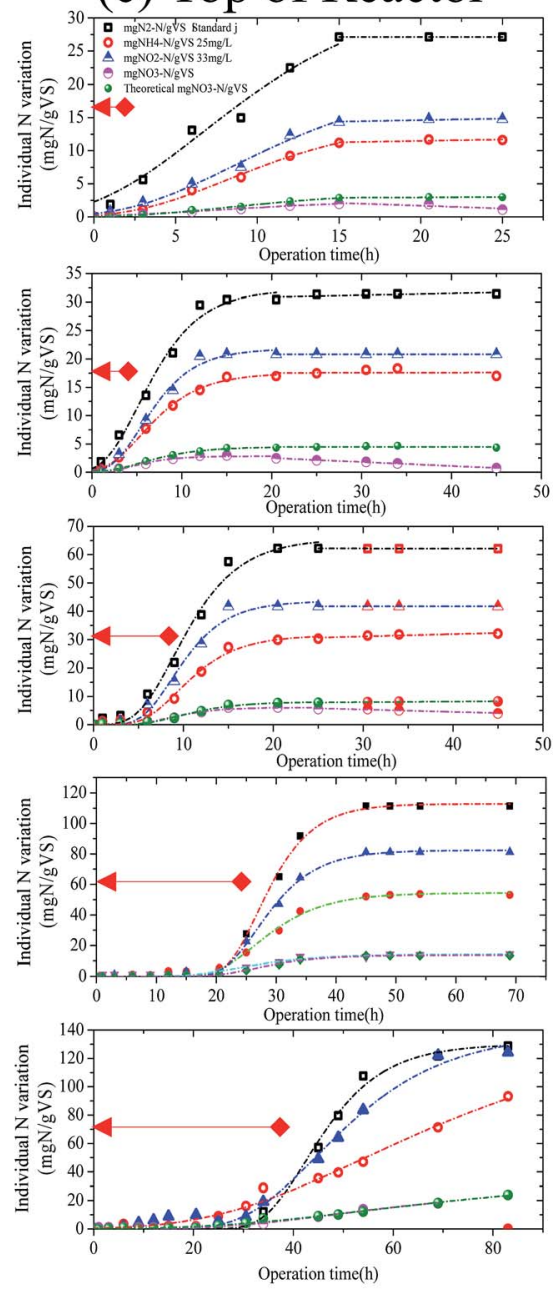

Fig. 1 Model simulation of the EGSB-anammox biomass reaction under different substrate concentrations.

Edwards model $: r=r_{\max }\left[\exp \left(-\frac{S}{K_{\mathrm{IE}}}\right)-\exp \left(-\frac{S}{K_{\mathrm{s}}}\right)\right]$

Eqn $(9)^{13}$,

$$
\text { Luong model }: r=\frac{r_{\max } S\left(1-S / S_{\mathrm{m}}\right)^{n}}{S+K_{\mathrm{s}}}
$$

Eqn $(10)^{14}$

$$
\text { Han-levenspiel model }: r=\frac{r_{\max } S\left(1-S / S_{\mathrm{m}}\right)^{n}}{S+K_{\mathrm{s}}\left(1-S / S_{\mathrm{m}}\right)^{m}}
$$

Eqn (11)

$$
\text { Monod equation }: r=r_{\max } \frac{S}{S+K_{\mathrm{s}}}
$$

$$
\text { Aiba equation : } r=r_{\max } \frac{S}{S+K_{\mathrm{s}}} \exp \left(-\frac{S}{K_{\mathrm{i}}}\right)
$$

where $r$ is the substrate degradation rate $\left(\mathrm{gN} \mathrm{gVSS}^{-1} \mathrm{~d}^{-1}\right), r_{\max }$ is the maximum substrate degradation rate $\left(\mathrm{gN} g \mathrm{gSS}^{-1} \mathrm{~d}^{-1}\right), S$ is the substrate concentration $\left(\mathrm{mg} \mathrm{L}^{-1}\right) ; K_{\mathrm{S}}$ is the half-saturation coefficient ( $\left.\mathrm{mg} \mathrm{L}^{-1}\right) ; K_{\mathrm{IH}}$ is the Haldane inhibition coefficient $\left(\mathrm{mg} \mathrm{L}^{-1}\right) ; K_{\mathrm{IE}}$ is the Edwards inhibition coefficient $\left(\mathrm{mg} \mathrm{L}^{-1}\right) ; K_{\mathrm{i}}$ is the Aiba inhibition coefficient $\left(\mathrm{mg} \mathrm{L}^{-1}\right) S_{m}$ is the critical inhibitory concentration above which reactions stops $\left(\mathrm{mg} \mathrm{L}^{-1}\right)$, and $n$ and $m$ are two empirical constants. The kinetic parameters were estimated using nonlinear regression method in origin (version 8.6).

\section{Results and discussion}

Reaction performance of continuous experiments and batch experiments

The continuous EGSB-anammox reactor was inoculated with two kinds of seeding sludge with a total of $5 \mathrm{~L}$, the initial HRT was set at $24 \mathrm{~h}$, and the initial influent ammonium and nitrite 
Table 2 Comparison of anammox performance in different reactors and kinetic parameters of anammox biomass $^{a}$

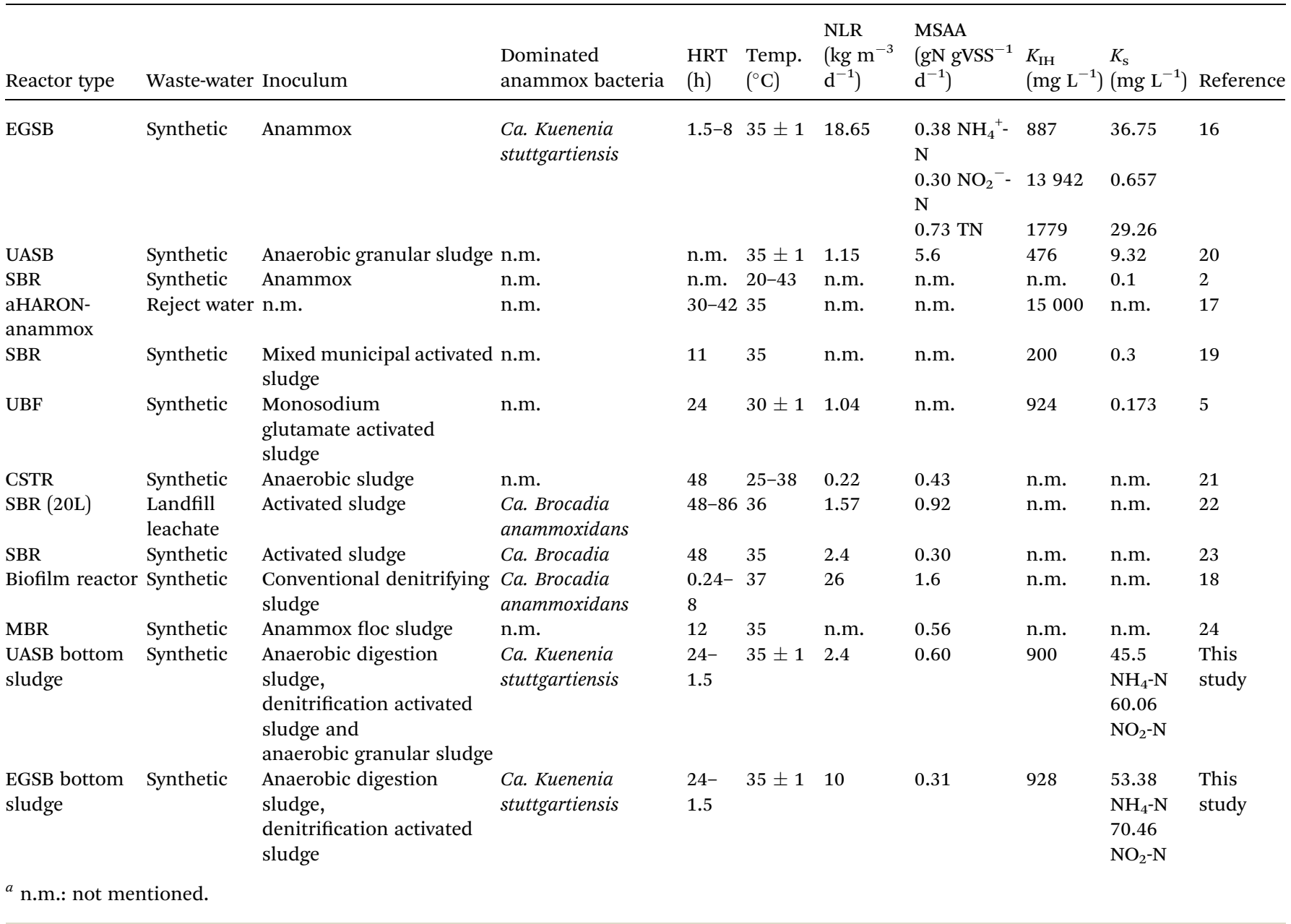

concentrations were 112.8 and $140.4 \mathrm{mg} \mathrm{N} \mathrm{L}^{-1}$ with a initial nitrogen loading rate (NLR) of $0.76 \mathrm{~kg} \mathrm{~N} \mathrm{~m}^{-3} \mathrm{~d}^{-1}$. While keeping the other operational parameters constant, the NLR was enhanced up to $4 \mathrm{~kg} \mathrm{~N} \mathrm{~m}{ }^{-3} \mathrm{~d}^{-1}$ either by increasing the influent substrate concentrations or shortening the HRT from 24 h to 1.5 h. After continuous operation, the influent ammonium and nitrite concentrations were elevated to $427.7,470.9 \mathrm{mg} \mathrm{N} \mathrm{L}{ }^{-1}$, respectively. The results indicated extremely high substrate conversion efficiencies (ammonium 90.6\%, nitrite 99.5\%, and a TN removal efficiency of around $89 \%$ ) with the NLR and NRR as high as 10 and $9 \mathrm{~kg} \mathrm{~N} \mathrm{~m}^{-3} \mathrm{~d}^{-1}$, respectively. Similarly in the UASB reactor, the NLR increased from 0.2 to $2.4 \mathrm{~kg} \mathrm{~N} \mathrm{~m}^{-3} \mathrm{~d}^{-1}$ and the NRR increased to $2.0 \mathrm{~kg} \mathrm{~N} \mathrm{~m} \mathrm{~N}^{-3} \mathrm{~d}^{-1}$ in the steady stage.

In the batch experiment, it was shown that three reactions were dominant in the anammox process in the vial (see Fig. 1). The start up of anammox enrichment has four consecutive phases: the cell lysis phase, the lag phase, activity elevation phase and stationary phase. In a situation similar to startup but with a different reaction sequence, three major bioprocesses of the anammox reaction were quantified in the reaction and from the perspective of microbial growth: the anammox reaction, denitrification and cell lysis. ${ }^{3}$ After the fast biogas production stage finished, denitrification and cell lysis were the two sequential leading reactions. Anammox activity was negligible once the anammox cell decayed and cell lysis became predominant in the vial. The density of the anammox cell gradually became less as the denitrifying cell thrived in the presence of $\mathrm{NO}_{3}-\mathrm{N}$ and organic matter.

The theoretical $\mathrm{NO}_{3}{ }^{-}-\mathrm{N}$ production ratio and the measured concentration were compared for each vial (Table 2). The increased ratio of $\mathrm{NO}_{3}{ }^{-} \mathrm{N}$ was adjusted to the anammox reaction followed the increase in the biogas production ratio. However, with an increased amount of feeding substrate the reaction time of anammox became longer, and the increase in the ratio of $\mathrm{NO}_{3}{ }^{-}-\mathrm{N}$ was caused by the high substrate concentration. The dominance of denitrification was indicated by the start of the decrease in the $\mathrm{NO}_{3}{ }^{-}-\mathrm{N}$ concentration in the vial. The reaction ratio is summarized in Table 2 with a comparison of the lag phase times under different initial substrate concentrations. The EGSB-anammox biomass showed that the lag time increased from 0.75 to 51.79 hours for nitrogen gas production. A high concentration and longer lag phase were shown in the batch analysis. The lag phase time for $\mathrm{NH}_{4}{ }^{+} \mathrm{N}$ removal was in accordance with gas production from $0.1 \mathrm{~h}$ to 
Table 3 Simulation result of anammox reaction and denitrification of EGSB-anammox biomass

\begin{tabular}{|c|c|c|c|c|c|c|c|c|c|c|}
\hline \multirow[b]{2}{*}{ Substrate } & \multicolumn{2}{|l|}{$\begin{array}{l}50 \\
\mathrm{mg} \mathrm{NH_{4 }}{ }^{+}-\mathrm{N} \mathrm{L}^{-1}\end{array}$} & \multicolumn{2}{|l|}{$\begin{array}{l}100 \\
\mathrm{mg} \mathrm{NH}_{4}{ }^{+}-\mathrm{N} \mathrm{L}^{-1}\end{array}$} & \multicolumn{2}{|l|}{$\begin{array}{l}200 \\
\mathrm{mg} \mathrm{NH}_{4}{ }^{+}-\mathrm{N} \mathrm{L}^{-1}\end{array}$} & \multicolumn{2}{|l|}{$\begin{array}{l}300 \\
\mathrm{mg} \mathrm{NH}_{4}{ }^{+}-\mathrm{N} \mathrm{L}^{-1}\end{array}$} & \multicolumn{2}{|l|}{$\begin{array}{l}400 \\
\mathrm{mg} \mathrm{NH}_{4}{ }^{+}-\mathrm{N} \mathrm{L}^{-1}\end{array}$} \\
\hline & $\begin{array}{l}r_{\max }(\mathrm{mg} \mathrm{N} \\
\mathrm{g}^{-1}(\mathrm{VSS})^{-1} \text { per h) }\end{array}$ & $R^{2}$ & $\begin{array}{l}r_{\max }(\mathrm{mg} \mathrm{N} \\
\left.\mathrm{g}^{-1}(\mathrm{VSS})^{-1} \text { per } \mathrm{h}\right)\end{array}$ & $R^{2}$ & $\begin{array}{l}r_{\max }(\mathrm{mg} \mathrm{N} \\
\left.\mathrm{g}^{-1}(\mathrm{VSS})^{-1} \text { per } \mathrm{h}\right)\end{array}$ & $R^{2}$ & $\begin{array}{l}r_{\max }(\mathrm{mg} \mathrm{N} \\
\left.\mathrm{g}^{-1}(\mathrm{VSS})^{-1} \text { per } \mathrm{h}\right)\end{array}$ & $R^{2}$ & $\begin{array}{l}r_{\max }(\mathrm{mg} \mathrm{N} \\
\left.\mathrm{g}^{-1}(\mathrm{VSS})^{-1} \text { per } \mathrm{h}\right)\end{array}$ & $R^{2}$ \\
\hline \multicolumn{11}{|l|}{ Bottom-annamox } \\
\hline $\mathrm{N}_{2}$ biogas & $3.8 \pm 0.60$ & 0.97 & $8.06 \pm 1.53$ & 0.97 & $8.96 \pm 0.77$ & 0.98 & $8.37 \pm 0.73$ & 0.99 & $4.02 \pm 1.34$ & 0.97 \\
\hline $\mathrm{NH}_{4}^{+}$ & $1.61 \pm 0.17$ & 0.96 & $3.21 \pm 0.75$ & 0.96 & $4.78 \pm 0.35$ & 0.99 & $2.52 \pm 0.18$ & 0.98 & $1.71 \pm 0.21$ & 0.98 \\
\hline $\mathrm{NO}_{2}^{-}$ & $2.50 \pm 0.48$ & 0.96 & $6.85 \pm 1.34$ & 0.98 & $6.44 \pm 0.51$ & 0.99 & $3.57 \pm 0.30$ & 0.96 & $2.59 \pm 0.32$ & 0.96 \\
\hline $\mathrm{NO}_{3}^{-}$ & $1.10 \pm 3.58$ & 0.95 & $2.21 \pm 1.01$ & 0.98 & $2.21 \pm 1.01$ & 0.98 & $1.08 \pm 0.15$ & 0.98 & $0.37 \pm 0.03$ & 0.98 \\
\hline Theoretical $\mathrm{NO}_{3}{ }^{-}$ & $0.45 \pm 0.07$ & 0.96 & $0.82 \pm 0.19$ & 0.96 & $1.34 \pm 0.09$ & 0.99 & $0.64 \pm 0.04$ & 0.98 & $0.43 \pm 0.05$ & 0.98 \\
\hline \multicolumn{11}{|c|}{$\lambda-$ lag time of reaction } \\
\hline $\mathrm{N}_{2}$ biogas & $0.75 \pm 0.73$ & 0.97 & $2.46 \pm 0.79$ & 0.97 & $5.38 \pm 0.61$ & 0.98 & $18.68 \pm 0.85$ & 0.99 & $51.79 \pm 13.48$ & 0.97 \\
\hline $\mathrm{NH}_{4}^{+}$ & $0.10 \pm 0.70$ & 0.96 & $2.39 \pm 0.97$ & 0.96 & $6.26 \pm 0.42$ & 0.99 & $8.75 \pm 1.29$ & 0.98 & $25.23 \pm 7.02$ & 0.98 \\
\hline $\mathrm{NO}_{2}^{-}$ & $0.73 \pm 0.84$ & 0.96 & $3.68 \pm 0.61$ & 0.98 & $5.30 \pm 0.50$ & 0.99 & $7.42 \pm 2.68$ & 0.96 & $27.84 \pm 6.37$ & 0.96 \\
\hline $\mathrm{NO}_{3}^{-}$ & 8.69 & 0.95 & $5.26 \pm 0.40$ & 0.98 & $5.26 \pm 0.40$ & 0.98 & $21.60 \pm 1.09$ & 0.98 & $40.08 \pm 2.01$ & 0.98 \\
\hline Theoretical $\mathrm{NO}_{3}{ }^{-}$ & $0.51 \pm 0.79$ & 0.96 & $2.39 \pm 0.97$ & 0.96 & $7.65 \pm 0.34$ & 0.99 & $8.86 \pm 1.24$ & 0.98 & $25.23 \pm 7.02$ & 0.98 \\
\hline
\end{tabular}

\section{Denitrification reaction}

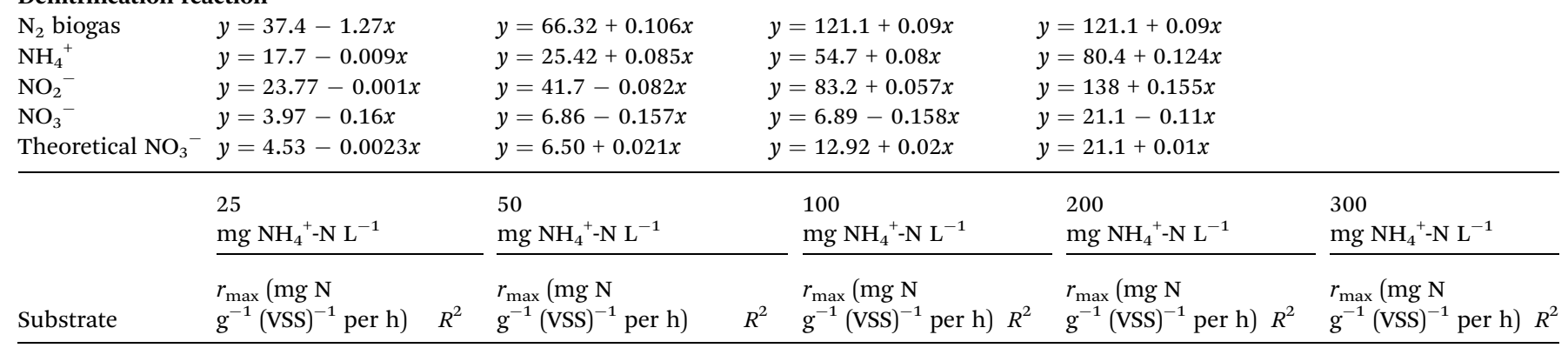

\section{Middle-anammox}

$\begin{array}{ll}\mathrm{N}_{2} \text { biogas } & 3.51 \pm 0.37 \\ \mathrm{NH}_{4}{ }^{+} & 1.64 \pm 0.17 \\ \mathrm{NO}_{2}{ }^{-} & 2.32 \pm 0.24 \\ \mathrm{NO}_{3}{ }^{-} & 0.28 \pm 0.05 \\ {\text { Theoretical } \mathrm{NO}_{3}{ }^{-}}^{-} & 0.34 \pm 0.03\end{array}$

Theoretical $\mathrm{NO}_{3}{ }^{-} 0.34 \pm 0.03$

\section{$\lambda$ - lag time of reaction}

$\begin{array}{ll}\mathrm{N}_{2} \text { biogas } & 0.96 \pm 0.48 \\ \mathrm{NH}_{4}{ }^{+} & 1.31 \pm 0.53 \\ \mathrm{NO}_{2}{ }^{-} & 1.78 \pm 0.49 \\ \mathrm{NO}_{3}{ }^{-} & 5 \times 10^{-17} \\ \text { Theoretical } \mathrm{NO}_{3}{ }^{-} & 3.3 \times 10^{-17}\end{array}$

\section{Denitrification reaction}

$\begin{array}{llrl}\mathrm{N}_{2} \text { biogas } & y & =33.68+0.001 x \\ \mathrm{NH}_{4}{ }^{+} & y & =16.01+0.064 x \\ \mathrm{NO}_{2}{ }^{-} & y & =21.96+0.0001 x \\ \mathrm{NO}_{3}{ }^{-} & y & =3.66-0.06 x \\ \text { Theoretical } \mathrm{NO}_{3}{ }^{-} & y & =4.09+0.016 x\end{array}$

\begin{abstract}
$0.98 \quad 5.08 \pm 0.57$
$0.98 \quad 2.04 \pm 0.23$

$0.983 .65 \pm 0.37$

$\begin{array}{ll}0.92 & 0.65 \pm 0.10\end{array}$

$0.96 \quad 0.52 \pm 0.06$
\end{abstract}

$\begin{array}{ll}0.98 & 3.33 \pm 0.69 \\ 0.98 & 0.66 \pm 0.95 \\ 0.98 & 3.11 \pm 0.64 \\ 0.92 & 3.87 \pm 0.80 \\ 0.96 & 0.66 \pm 0.95\end{array}$
$0.987 .51 \pm 0.86$

$\begin{array}{lll}0.98 & 2.40 \pm 0.25\end{array}$

$0.983 .48 \pm 0.40$

$0.920 .78 \pm 0.12$

$0.960 .62 \pm 0.06$ $\begin{array}{lll}0.98 & 7.51 \pm 0.86\end{array}$

$\begin{array}{lll}0.97 & 2.41 \pm 0.25\end{array}$

$0.963 .49 \pm 0.40$

$0.970 .78 \pm 0.11$

$0.970 .62 \pm 0.06$
$0.98-$

$0.97-$

$0.96-$

$0.97-$

$0.97-$
0.97

0.98

0.98

0.98 
Table 3 (Contd.)

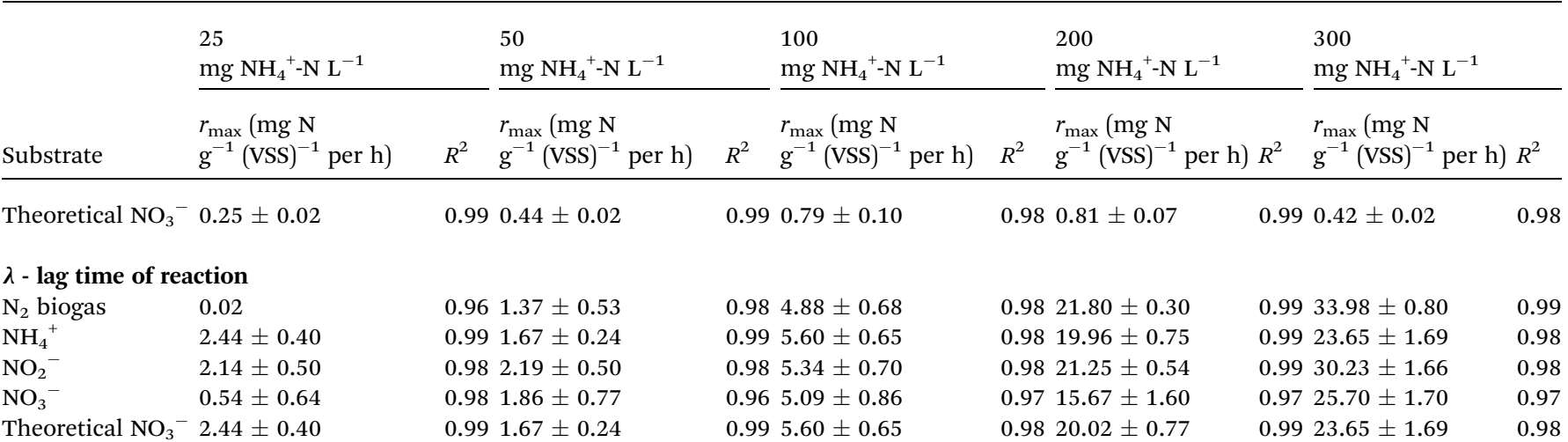

\section{Denitrification reaction}

$\begin{array}{llll}\mathrm{N}_{2} \text { biogas } & y=27.13+0.000106 x & y=30.2+0.032 x & y=62.28+0.0032 x \\ \mathrm{NH}_{4}{ }^{+} & y=10.64+0.048 x & y=17.47+0.0027 x & y=28.66+0.0825 x \\ \mathrm{NO}_{2}{ }^{-} & y=13.7+0.042 x & y=20.82 & y=41.74 \\ \mathrm{NO}_{3}{ }^{-} & y=3.37-0.084 x & y=3.92-0.07025 x & y=7.90-0.0844 x \\ \text { Theoretical NO }_{3}{ }^{-} y=2.72+0.0108 x & y=4.47+0.0007 x & y=7.34+0.021 x\end{array}$

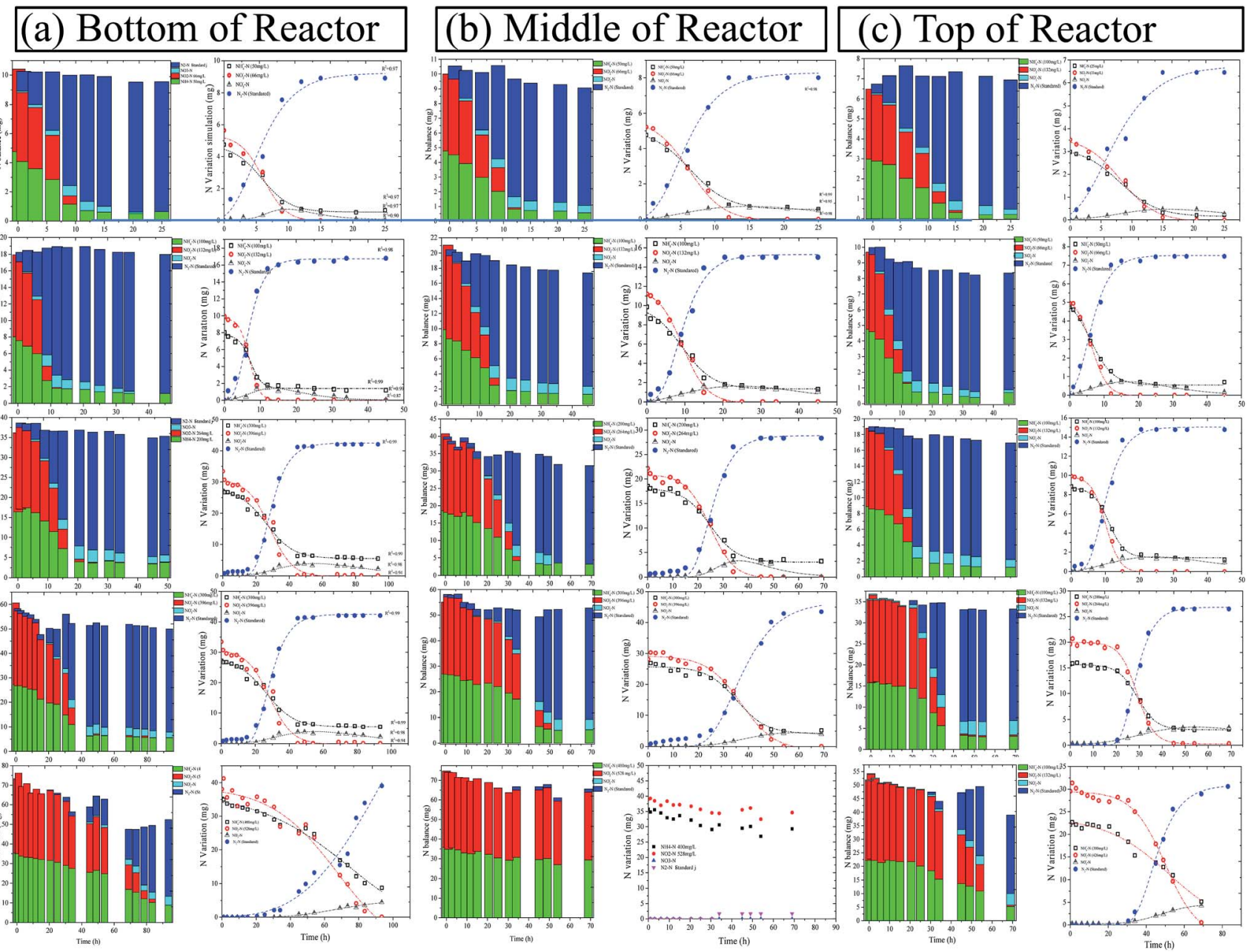

Fig. 2 Mass balance and quality control of the individual $\mathrm{N}$ variations in vials over time. 

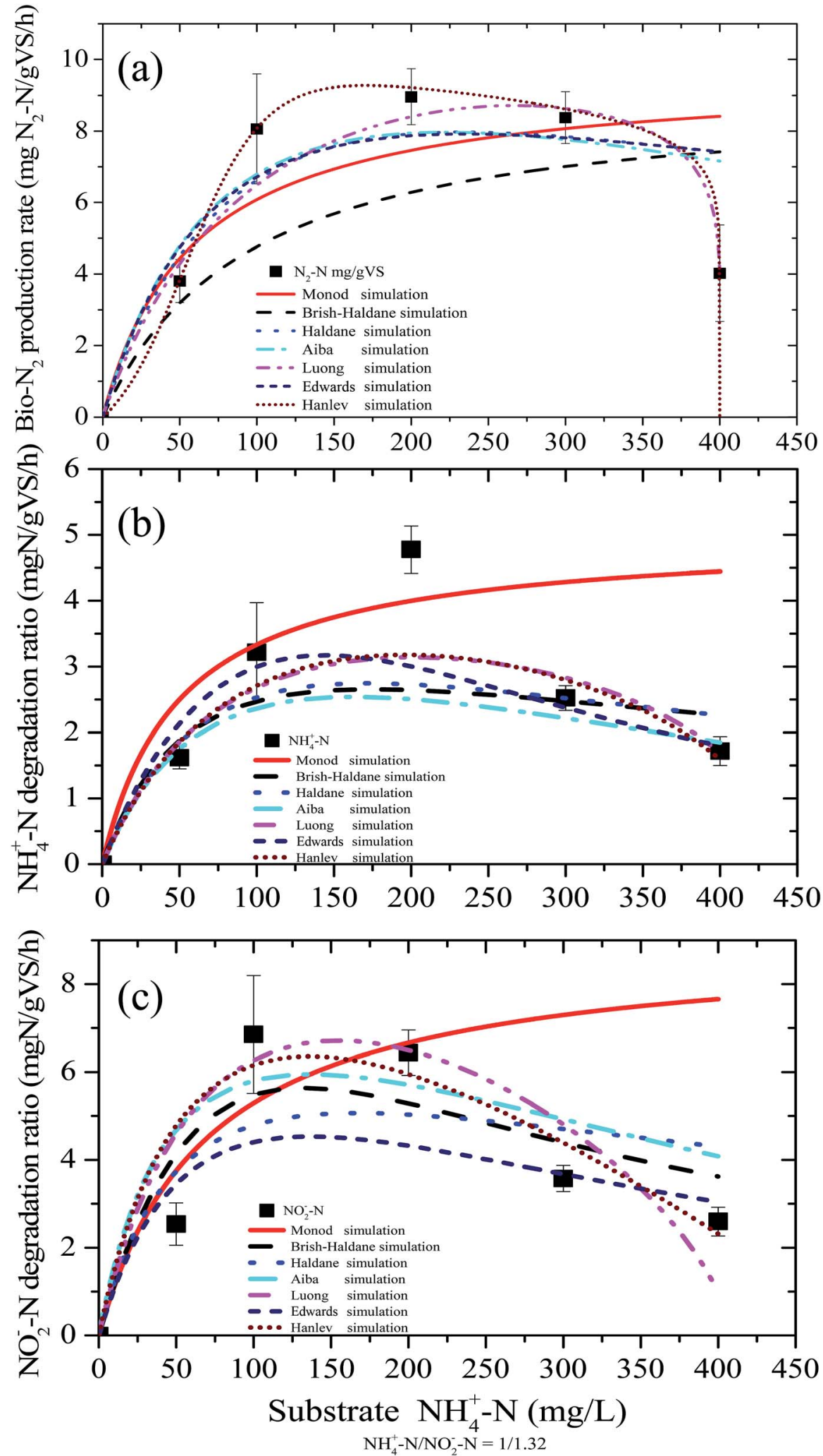

Fig. 3 A comparison of simulations of different kinetic models used for SAA of individual nitrogen consumption rate.

25.23 hours and $\mathrm{NO}_{2}{ }^{-}-\mathrm{N}$ increased from 0.73 to 27.84 hours. The delay of $5 \mathrm{~h}$ for nitrate production is evidence that the anammox reaction was the main reaction in the beginning.

\section{Kinetic evaluation and batch model assessment}

Kinetic characteristics of ammonium conversion. The biodegradation kinetics of anammox mixed culture in EGSB 

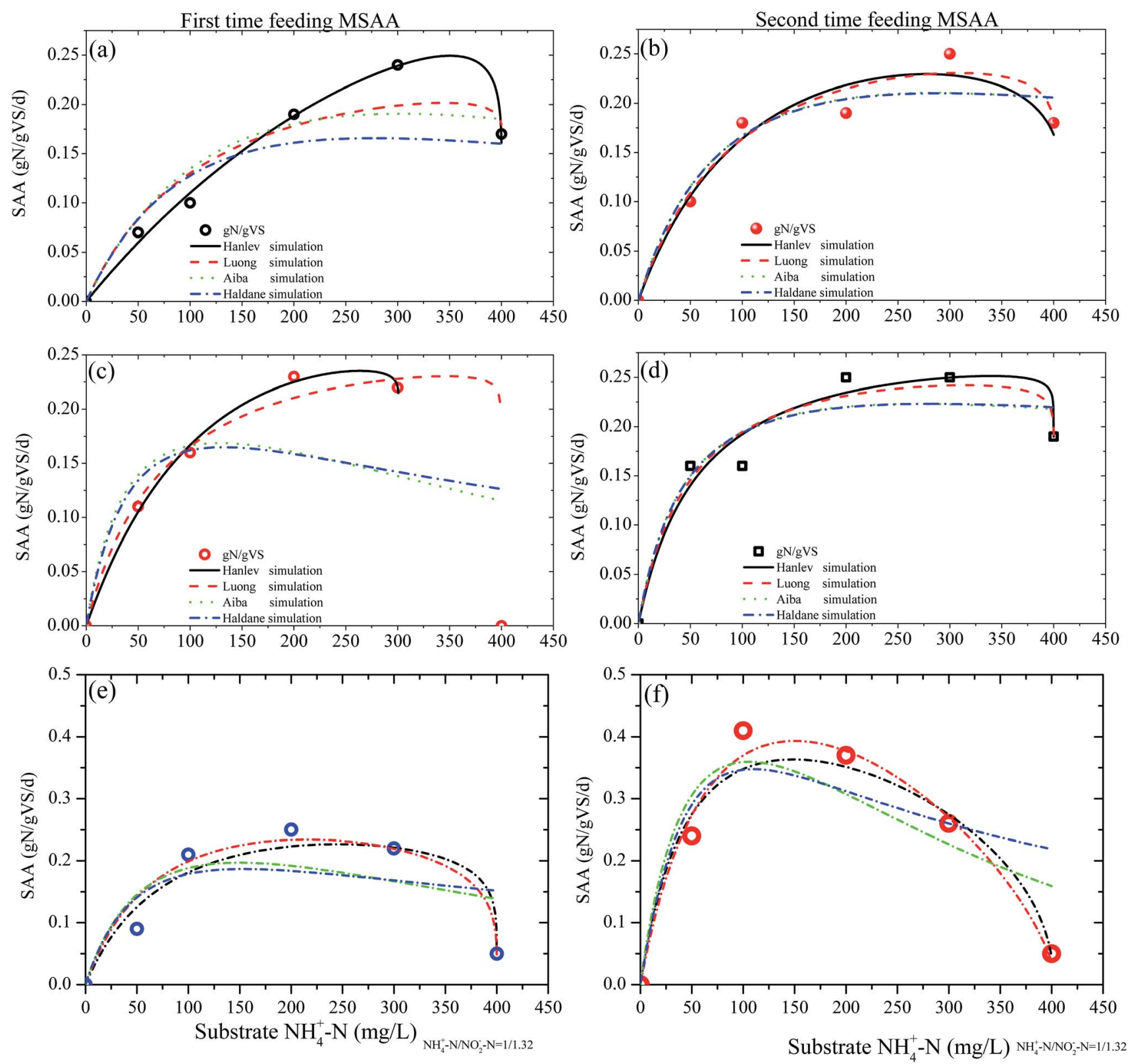

Fig. 4 SAA kinetic simulation of the first and second feeding on EGSB-anammox biomass, first SAA of (a) top sludge, (c) middle sludge, (e) bottom sludge; the second SAA for (b) top sludge, (d) middle sludge, ( $f$ ) bottom sludge.

and UASB were studied for the initial TN concentration range of 100-1200 $\mathrm{mg} \mathrm{L}^{-1}$. The information given in Table 3 demonstrates the effect of initial concentrations on specific ammonium conversion efficiency. The lag phase times which respond to the effect of the initial substrate concentration on biomass activity were obtained in the series test. For $\mathrm{NH}_{4}{ }^{+}-\mathrm{N}$ degradation, the lag time increased from $0.1 \mathrm{~h}$ of $50 \mathrm{mg} \mathrm{NH}_{4}^{+}-\mathrm{N} \mathrm{L}^{-1}$ to $25.23 \mathrm{~h}$ over the concentration of $400 \mathrm{mg} \mathrm{NH}_{4}^{+}-\mathrm{N} \mathrm{L}^{-1}$ (Fig. 1a). The lag time of the reaction under different concentrations of substrate grows exponentially. The lag time of the substrate 400 $\mathrm{mg} \mathrm{NH}_{4}^{+}-\mathrm{N} \mathrm{L}^{-1}$ was 25.23 hours, which means more than one day was required to acclimatize the biomass enriched under low substrate concentrations to a high concentration. Moreover, the $r_{\text {max }}$ in substrate of $50 \mathrm{mg} \mathrm{NH}_{4}{ }^{+}-\mathrm{N} \mathrm{L}^{-1}$ was almost equal to the $r_{\text {max }}$ under $400 \mathrm{mg} \mathrm{NH}_{4}{ }^{+}-\mathrm{N} \mathrm{L}^{-1}$, indicating that high activity in the anammox biomass is maintained over a range of substrate concentrations and tolerance over a certain concentration range in the absence of free ammonia and free nitrite acid.

Kinetic models were used for the SAA analysis of the different biomasses of the reactors. Data fitting with the Monod, Haldane, Aiba, Luong, Edwards and Hanlev models was carried out with Origin software version 8.6 (shown in Fig. 2). The accuracy test of the N-balance showed the errors were under $5 \%$. The simulation results suggested that the Aiba, Luong, Haldane and Hanlev models were the most appropriate kinetic models, which effectively explained the process with correlation coefficients higher than the other models for $\mathrm{N}_{2}$ gas production, $\mathrm{NH}_{4}{ }^{+}-\mathrm{N}$ conversion and $\mathrm{NO}_{2}-\mathrm{N}$ conversion (Fig. 3). Among of the four kinds of 
Table 4 The most suitable kinetic models for $\mathrm{N}_{2}, \mathrm{NH}_{4}{ }^{+}-\mathrm{N}$ and $\mathrm{NO}_{2}{ }^{-}-\mathrm{N}$ conversion

\begin{tabular}{|c|c|c|c|c|c|c|c|c|c|}
\hline & & \multicolumn{4}{|c|}{ First time feeding } & \multicolumn{4}{|c|}{ Second time feeding } \\
\hline & $K_{\mathrm{s}} \mathrm{mg} \mathrm{L}^{-1}$ & 49.95 & 90.61 & 79.57 & 54.08 & 50.32 & 53.38 & 52.52 & 48.65 \\
\hline & $K_{\mathrm{i}} \mathrm{mg} \mathrm{L}^{-1}$ & 458.98 & 301.08 & 398.92 & 321.99 & 1713.56 & 400 & 400.09 & 1645.89 \\
\hline & $n$ & & 1.549 & 0.028 & & & 0.85 & 0.039 & \\
\hline \multirow[t]{6}{*}{$\mathrm{NH}_{4}{ }^{-}-\mathrm{N}$ conversion } & $r_{\max } \mathrm{g} \mathrm{N} \mathrm{g}^{-1}(\mathrm{VSS})^{-1}$ & 0.55 & 0.36 & 0.3 & 0.35 & 0.38 & 0.35 & 0.35 & 0.36 \\
\hline & $K_{\mathrm{s}} \mathrm{mg} \mathrm{L}^{-1}$ & 250.82 & 277.74 & 130.05 & 154.39 & 107.95 & 120.11 & 109.57 & 103.3 \\
\hline & $K_{\mathrm{i}} \mathrm{mg} \mathrm{L}^{-1}$ & 666.71 & 400.43 & 401.81 & 500 & 1033.67 & 411.72 & 402.11 & 818.14 \\
\hline & $n$ & & 0.86 & 0.05 & & & 0.58 & 0.08 & \\
\hline & $m$ & & 0.12 & & & & 0.19 & & \\
\hline & $R^{2}$ & 0.82 & 0.96 & 0.81 & 0.76 & 0.88 & 0.89 & 0.91 & 0.88 \\
\hline & $m$ & & 0.48 & & & & 0.17 & & \\
\hline & $R^{2}$ & 0.39 & 0.93 & 0.92 & 0.37 & 0.59 & 0.87 & 0.9 & 0.51 \\
\hline
\end{tabular}

selected kinetic models simulated on the bottom of the EGSBanammox biomass (Fig. 3 and 4), the kinetic parameters simulated from Haldane were $0.30 \mathrm{gN} \mathrm{gVSS}^{-1} \mathrm{~d}^{-1}$ with $K_{\mathrm{s}}$ of $54.08 \mathrm{mg}$

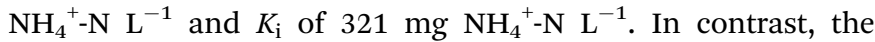
simulation using the Loung model indicated $0.30 \mathrm{gN} \mathrm{gVSS}^{-1} \mathrm{~d}^{-1}$ with $K_{\mathrm{S}}$ of $79.59 \mathrm{mg} \mathrm{NH}_{4}{ }^{+}-\mathrm{N} \mathrm{L}^{-1}$ and $K_{\mathrm{i}}$ of $398.82 \mathrm{mg} \mathrm{NH}_{4}{ }^{+}-\mathrm{N} \mathrm{L}^{-1}$. In the Hanlev model, the result was $0.25 \mathrm{gN} \mathrm{gVSS}^{-1} \mathrm{~d}^{-1}$ with $K_{\mathrm{s}}$ of $90.61 \mathrm{mg} \mathrm{NH_{4 }}{ }^{+}-\mathrm{N} \mathrm{L}^{-1}$ and $K_{\mathrm{i}}$ of $301 \mathrm{mg} \mathrm{NH}_{4}{ }^{+}-\mathrm{N} \mathrm{L}^{-1}$. In the selected Aiba model, the result was $0.31 \mathrm{~g} \mathrm{~N} \mathrm{~g}^{-1} \mathrm{gN} \mathrm{gVSS}^{-1} \mathrm{~d}^{-1}$ with $K_{\mathrm{s}}$ of $49.95 \mathrm{mg} \mathrm{NH}_{4}{ }^{+}-\mathrm{N} \mathrm{L}^{-1}$ and $K_{\mathrm{i}}$ of $459 \mathrm{mg} \mathrm{NH}_{4}{ }^{+}-\mathrm{N} \mathrm{L}^{-1}$. It should be noted that only the Luong and Hanlev models had correlation coefficients over 0.98 (see Table 4).

The inhibition constant $K_{\mathrm{i}}$ were also different for the $\mathrm{N}_{2}$ gas production reaction, $\mathrm{NH}_{4}{ }^{+}-\mathrm{N}$ conversion and $\mathrm{NO}_{2}{ }^{-}-\mathrm{N}$ conversion efficiency. The most appropriate kinetic model was the Hanlev model, with simulated results of $K_{\mathrm{i}} 301 \mathrm{mg} \mathrm{NH}_{4}{ }^{+}-\mathrm{N} \mathrm{L}^{-1}$ for $\mathrm{N}_{2}$ gas production, $K_{\mathrm{i}}$ of $400 \mathrm{mg} \mathrm{NH_{4 }}{ }^{+}-\mathrm{N} \mathrm{L}^{-1}$ for $\mathrm{NH}_{4}{ }^{+}$ conversion and $K_{\mathrm{i}}$ of $402 \mathrm{mg} \mathrm{NH}{ }_{4}^{+}{ }^{-} \mathrm{N} \mathrm{L}^{-1}$ for $\mathrm{NO}_{2}{ }^{-}$conversion, respectively. Simulation results were also obtained from the kinetic models for the middle and top of the EGSB reactor (Fig. 3 and 4). The highest $r_{\max }$ was obtained from the bottom of the EGSB-anammox biomass, and much higher than the middle and top of the EGSB-anammox biomass (see Table 3).

Kinetic characteristics of nitrite conversion. The effect of nitrite concentrations was also evaluated in the batch experiment, with the simulation results summarized in Table 4 . It is evident from Fig. 3 and 4 that the Hanlev and Luong models were both capable of reliably describing nitrite conversion with correlation coefficients of $0.92,0.92$, respectively. Thus, the Hanlev and Luong models were also suitable for the characterization of the kinetic characteristics for nitrite. Based on the Hanlev model, the $r_{\max }, K_{\mathrm{s}}$ and $K_{\mathrm{i}}$ of nitrite were $0.55 \mathrm{~g} \mathrm{~N} \mathrm{~g}^{-1} \mathrm{~V}^{-1}$ $\mathrm{s}^{-1}, 50.13 \mathrm{mg} \mathrm{NH}{ }_{4}^{+}-\mathrm{N} \mathrm{L}^{-1}$ and $402.73 \mathrm{mg} \mathrm{NH}_{4}{ }^{+}-\mathrm{N} \mathrm{L}^{-1}$ which were higher than the experimental results.
Since substrate degradation is the result of microbial activity, the kinetics of contaminant degradation is closely related to the microbial condition. For $\mathrm{NO}_{2}{ }^{-} \mathrm{N}$ degradation, the lag time increased from $0.73 \mathrm{~h}$ of $50 \mathrm{mg} \mathrm{NH}_{4}{ }^{+}-\mathrm{N} \mathrm{L}^{-1}$ to $27.84 \mathrm{~h}$ for the concentration of $400 \mathrm{mg} \mathrm{NH}_{4}{ }^{+}-\mathrm{N} \mathrm{L}^{-1}$ (Fig. 1). Similarly, in the case of $\mathrm{NH}_{4}{ }^{+}$conversation, the $r_{\max }$ in the $50 \mathrm{mg} \mathrm{NH}_{4}{ }^{+}-\mathrm{N}$

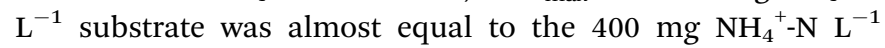
substrate. However, in the bottom of EGSB-anammox biomass, a difference was noted between $\mathrm{NO}_{2}{ }^{-} \mathrm{N}$ conversion and $\mathrm{NH}_{4}{ }^{+}$ conversion: analysis revealed ratios of 2.5/1.61 at $50 \mathrm{mg} \mathrm{NH}_{4}{ }^{-}-\mathrm{N}$ $\mathrm{L}^{-1}, 6.85 / 3.21$ at $100 \mathrm{mg} \mathrm{NH}_{4}{ }^{+} \mathrm{N} \mathrm{L}^{-1}, 6.44 / 4.78$ at $200 \mathrm{mg} \mathrm{NH}_{4}{ }^{+}$$\mathrm{N} \mathrm{L}^{-1}, 3.57 / 2.52$ at $300 \mathrm{mg} \mathrm{NH}{ }_{4}^{+}-\mathrm{N} \mathrm{L}^{-1}, 2.59 / 1.71$ at $400 \mathrm{mg}$ $\mathrm{NH}_{4}{ }^{+}-\mathrm{N} \mathrm{L}^{-1}$, respectively. Following the reduced amount of anammox biomass purification, the lag time of the reaction was increased. That is, at $200 \mathrm{mg} \mathrm{NH}_{4}{ }^{+}-\mathrm{N} \mathrm{L}^{-1}$, the lag time was $5 \mathrm{~h}$ at the bottom anammox biomass, $9.9 \mathrm{~h}$ in the middle biomass and $21.2 \mathrm{~h}$ in the top of the anammox biomass (Table 3). $\mathrm{The} \mathrm{NH}_{4}{ }^{+} \mathrm{-N}$ conversion results showed a similar trend: at high substrate concentrations, the conversion ratio of $\mathrm{NO}_{2}-\mathrm{N}$ was lower. The analytical results of the data suggested that the Aiba, Hanlev, Luong and Haldane models were suitable choices for describing the process, with correlation coefficients of $0.39,0.93,0.92$ and 0.37 , respectively (Table 4 ). The Hanlev and Luong models were the most appropriate models, with $K_{\mathrm{s}}$ of 50.13 and $99.35 \mathrm{mg}$ $\mathrm{NH}_{4}{ }^{+}-\mathrm{N} \mathrm{L}^{-1}$ and $K_{\mathrm{i}} 402.73$ and $405 \mathrm{mg} \mathrm{NH}_{4}{ }^{+}-\mathrm{N} \mathrm{L}^{-1}$, respectively. Compared with previous results (see Table 2), a significant difference in $K_{\mathrm{s}}$ in the reaction is illustrated by the mixed culture of anammox in the reactor. The low $K_{\mathrm{s}}$ but high $K_{\mathrm{i}}$ of $\mathrm{NO}_{2}{ }^{-} \mathrm{N}$ conversion has also reported by Chen, ${ }^{16}$ but an even higher $K_{\mathrm{i}}$ of $15000 \mathrm{mg} \mathrm{L}{ }^{-1}$ has been reported. ${ }^{17}$ In this study, the $K_{\mathrm{i}}$ value of $939 \mathrm{mg} \mathrm{N} \mathrm{L}^{-1}$ obtained from both from Hanlev and Luong models was consistent with other findings reported in the literature. ${ }^{5}$ 



Fig. 5 Characteristic of kinetics in the UASB-anammox under different substrate concentrations.

Kinetic characteristics of nitrogen conversion. For the total nitrogen conversion in the form of $\mathrm{N}_{2}$ gas, since the UASBanammox reactor has a misdistribution of biomass compared to the EGSB-anammox reactor, which can mix the biomass with recycled water, the activity at the bottom of the UASB-anammox is higher than in the middle and top biomass in the UASB

Table 5 Kinetic analysis of the bottom high purity UASB-anammox biomass

\begin{tabular}{|c|c|c|c|c|c|c|}
\hline \multicolumn{2}{|l|}{ Substrate } & \multirow{2}{*}{$\begin{array}{l}\text { Biogas production } \\
\mathrm{mg}_{2}-\mathrm{N} \mathrm{g}^{-1}(\mathrm{VSS})^{-1} \\
\text { per } \mathrm{h}\end{array}$} & \multirow{2}{*}{ 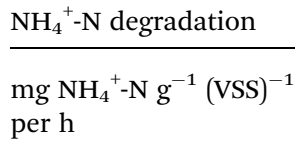 } & \multirow{2}{*}{ 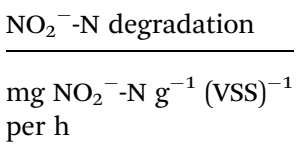 } & \multirow{2}{*}{$\begin{array}{l}\mathrm{NO}_{3}{ }^{-}-\mathrm{N} \text { production } \\
\begin{array}{l}\text { mg } \mathrm{NO}_{3}{ }^{-}-\mathrm{N} \mathrm{g}^{-1}(\mathrm{VSS})^{-1} \\
\text { per } \mathrm{h}\end{array}\end{array}$} & \multirow{2}{*}{$\begin{array}{l}\text { Theoretical } \mathrm{NO}_{3}{ }^{-}-\mathrm{N} \\
\mathrm{mg} \mathrm{NO}_{3}{ }^{-}-\mathrm{N} \mathrm{g}^{-1}(\mathrm{VSS})^{-1} \\
\text { per h }\end{array}$} \\
\hline $\begin{array}{l}\mathrm{NO}_{2}-\mathrm{N} \\
\left(\mathrm{mg} \mathrm{L}^{-1}\right)\end{array}$ & $\begin{array}{l}\mathrm{NH}_{4}^{+}-\mathrm{N} \\
\left(\mathrm{mg} \mathrm{L}^{-1}\right)\end{array}$ & & & & & \\
\hline 66 & 50 & $14.54 \pm 0.92$ & $3.89 \pm 0.91$ & - & $2.10 \pm 1.77$ & $0.09 \pm 0.023$ \\
\hline 132 & 100 & $28.24 \pm 1.43$ & $10.74 \pm 3.08$ & $17.63 \pm 2.7$ & $0.77 \pm 0.62$ & $0.28 \pm 0.08$ \\
\hline 264 & 200 & $18.06 \pm 1.01$ & $5.38 \pm 1.63$ & $7.73 \pm 2.2$ & $1.44 \pm 0.52$ & $0.14 \pm 0.04$ \\
\hline 396 & 300 & $11.43 \pm 0.54$ & $4.05 \pm 0.26$ & $6.02 \pm 0.99$ & $18.34 \pm 0.03$ & $0.10 \pm 0.006$ \\
\hline 528 & 400 & $13.43 \pm 0.27$ & $5.54 \pm 1.06$ & $18.35 \pm 3.86$ & $1.21 \pm 0.46$ & $0.32 \pm 0.075$ \\
\hline 660 & 500 & $2.86 \pm 0.04$ & $1.03 \pm 0.45$ & $1.50 \pm 0.22$ & $0.12 \pm 0.17$ & $3.35 \pm 0.21$ \\
\hline 792 & 600 & $0.34 \pm 0.02$ & $2.33 \pm 1.0$ & $0.07 \pm 0.096$ & $0.19 \pm 0.7$ & 0.24 \\
\hline
\end{tabular}



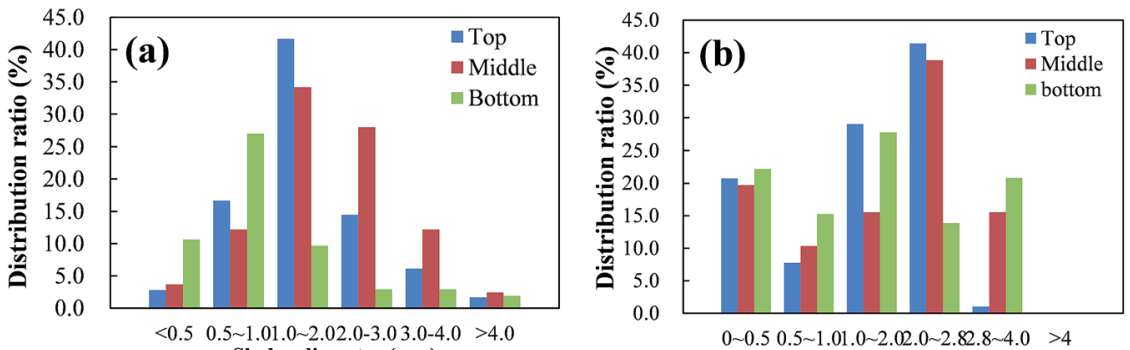

$<0.5 \quad 0.5 \sim 1.01 .0 \sim 2.02 .0-3.03 .0-4.0>4.0$
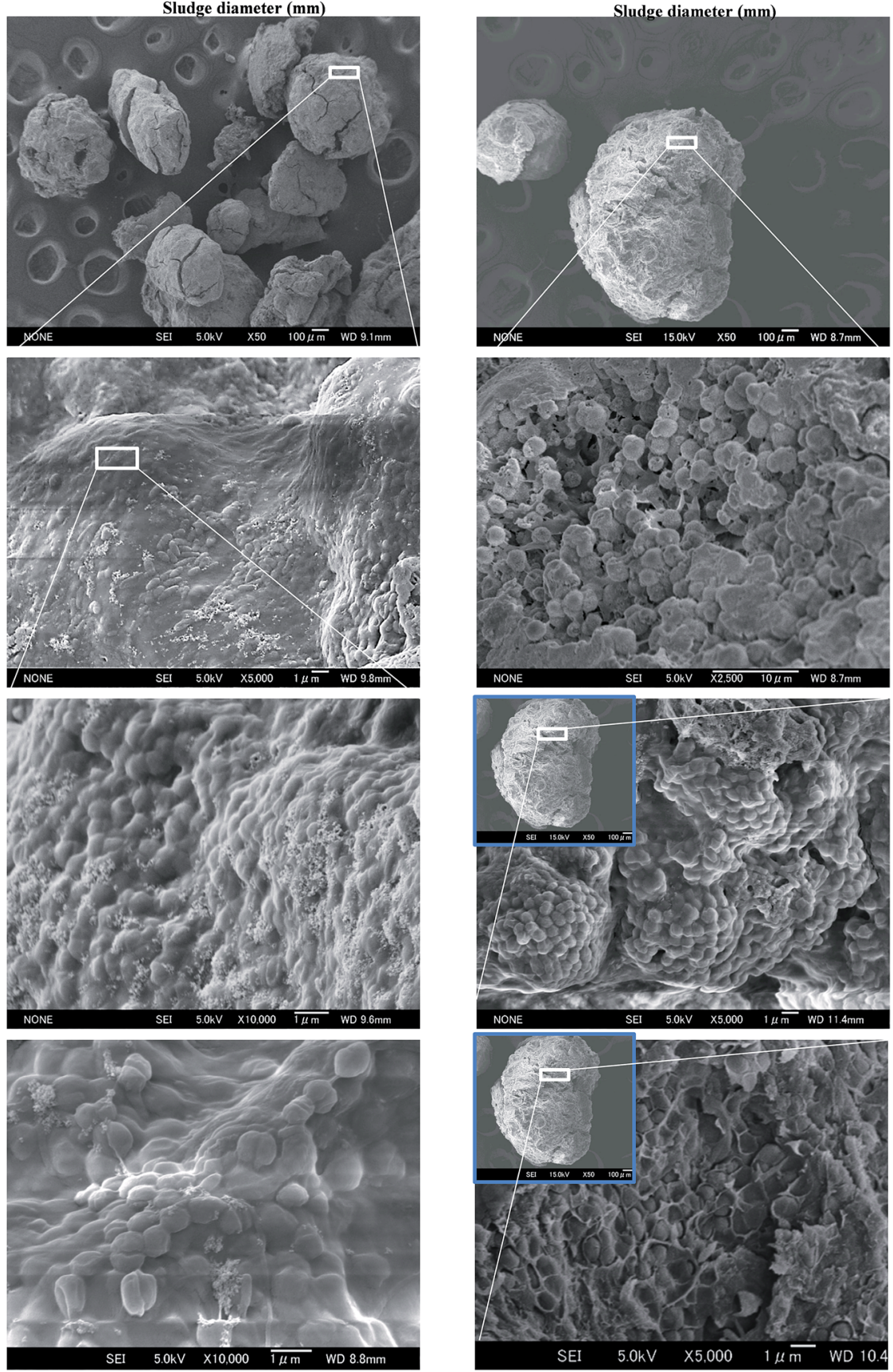

Fig. 6 Microcosmic characteristics (SEM) of the anammox sludge (a) UASB and (b) EGSB.

reactor. The kinetics of the UASB-anammox biomass at the top, middle and bottom of the reactor are shown in Fig. 5a-c. Since the feeding system of the UASB results in a decrease in substrate distribution according to height, a considerable gap in the SAA was found from the top, middle and bottom of the reactor biomass. In Table 5 , it can be seen that the highest MSAA, at 0.6 
gN $\mathrm{gVSS}^{-1} \mathrm{~d}^{-1}$, was in the bottom of the UASB-anammox biomass simulated with the Hanlev model, which was almost twice that of the SAA for the EGSB-anammox. However, the total conversion efficiency of the UASB-anammox reactor was much lower than the EGSB-anammox reactor (see Table 3) in this study due to the drawback of biomass misdistribution in the UASB-anammox according to its height. The microcosmic characteristics of the UASB-anammox biomass and EGSBanammox biomass are shown in Fig. 6, with the distribution of granular diameters indicated for the top of the reactor, and in the middle and at the bottom. While the average granular diameters were $0.5-1 \mathrm{~cm}$ at the bottom of the UASB-anammox biomass, in the middle and at the top of the reactor the granular diameter was between 1.0 and $2.0 \mathrm{~cm}$ with as generally normal distribution. In contrast, the diameters were mainly 1$2.8 \mathrm{~cm}$ and $<0.5 \mathrm{~cm}$ in the EGSB reactor, where distribution was aided by circulation. The SEM (scanning electron microscope) micro-characteristics of the anammox cell are also similar since the dominant anammox species are the same. It should be noted, however, that different morphological cells were detected in both of the biomasses as a result of the various metabolisms in the mixed culture (Fig. 6).

As contaminant degradation is the result of the microbial activity, the kinetics of contaminant degradation are closely related to the kinetics of microbial growth. The different dominant anammox species have different characteristics which determine the expression of enzyme activity. The relationship between the specific growth rate of a population of microorganisms and the substrate concentration is a valuable tool in understanding the biodegradation processes. Kinetic models showed that reaction performance is closely related to the microorganisms and the substrate. The evaluation of the kinetic parameters with the quality control of the $\mathrm{N}$ balance is shown in Fig. 2, and the effect of initial TN concentrations on the $\mathrm{N}$ conversion rates is shown in Table 2 . An analysis of the data suggests that the Aiba, Hanlev, Luong and Haldane models can suitably describe the anammox process, with correlation coefficients of 0.39, 0.99, 0.98 and 0.34, respectively (Table 4). Among these four models, the Luong model and the Hanlev model were found to fit the experimental data well with high coefficients of determination, $\left(R^{2}\right)$, at 0.965 and 0.984 , respectively. The Hanlev and Luong models provided the best simulation results, with $r_{\max }$ at 0.25 and $0.3 \mathrm{gN} \mathrm{gVSS}^{-1} \mathrm{~d}^{-1}, K_{\mathrm{s}}$ were 90.6 and $79.57 \mathrm{mg} \mathrm{NH}_{4}^{+}-\mathrm{N} \mathrm{L}^{-1}$ and $K_{\mathrm{i}}$ were 301 and $398 \mathrm{mg}$ $\mathrm{NH}_{4}{ }^{+}-\mathrm{N} \mathrm{L}^{-1}$, respectively. However, according to $R^{2}$ and the fit curves, the Hanlev model was a better fit than the Luong model. Compared to the first feeding, the second feeding resulted in an increased SAA for the bottom of the EGSB biomass with an $r_{\max }$ of 0.28 and $0.3 \mathrm{gN} \mathrm{gVSS}^{-1} \mathrm{~d}^{-1}, K_{\mathrm{s}}$ of 53.38, $52.52 \mathrm{mg} \mathrm{NH}_{4}^{+}-\mathrm{N} \mathrm{L}^{-1}$ and $K_{\mathrm{i}}$ of 400 and $400 \mathrm{mg} \mathrm{NH}_{4}{ }^{+}-\mathrm{N} \mathrm{L}^{-1}$, respectively. It should be noted that the reactor performance remained stable and efficiency remained high in the present study even when the nitrogen concentrations exceeded $1000 \mathrm{mg} \mathrm{N} \mathrm{L}^{-1}$, indicating that the anammox-EGSB reactor was able to tolerate high ammonium concentrations. This suggests that an anammox process capable of tolerating high substrate concentrations would reduce the engineering investment and operation costs.
A long lag time was found to correspond to an increase in the mixed culture substrate, illustrating that a high substrate concentration has a significant effect on the anammox biomass and contributes to the process inhibition.

\section{Batch kinetic model assessment}

The highest MSAA previously reported was $1.6 \mathrm{gN} \mathrm{gVSS}^{-1} \mathrm{~d}^{-1}$ and was cultured in a biofilm reactor. ${ }^{18}$ In most other reports, the MSSA varies from 0.1 to $0.5 \mathrm{gN} \mathrm{gVSS}^{-1} \mathrm{~d}^{-1}$ (see Table 2). In this study, the results from the first feeding of SAA and the second feeding of anammox SAA indicated that the Hanlev and Luong models are the best models for analyzing the anammox biomass. The second feeding increased the SAA of the anammox biomass, especially in the bottom sludge, which has a higher purity (Fig. 4). Hanlev's kinetic model was the best fit for the experimental data for the $\mathrm{NH}_{3}-\mathrm{N}$ and $\mathrm{NO}_{2}-\mathrm{N}$ conversation, with correlation coefficients of $R^{2}=0.96$ and 0.93, respectively. The Luong model also fitted the mixed reaction well, as has been reported by Strous. ${ }^{2}$ Based on the model simulations, the anammox reaction was completely inhibited at a TN concentration around $1000 \mathrm{mg} \mathrm{L}^{-1}$, which confirmed the suitability of the anammox process for the treatment of highstrength wastewater. There have been different values of $K_{\mathrm{s}}$ reported in the research, including $K_{\mathrm{s}}$ of $0.657 \mathrm{mg} \mathrm{L}^{-1},{ }^{16} 0.3 \mathrm{mg}$ $\mathrm{L}^{-1}$ (ref. 19) and even a low of $0.173 \mathrm{mg} \mathrm{L}^{-1} .5$ In this study, as the simulation using the Hanlev model at second feeding suggests, the high $K_{\mathrm{s}}$ value of $53.38 \mathrm{mg} \mathrm{L}^{-1}$ may be attributed to the mixed culture with functional substrate conversion. The Luong and Hanlev models were the best fitting models to describe the characteristics and kinetics of the mixed culture anammox biomass.

It should be point that the simple models only describe the dependence of the biodegradation rate on biomass concentration. The results obtained from this study can be used to predict the reactor performance and as a guide for necessary changes in the operation conditions, especially with regard to NLR modifications and changes in the substrate concentration. The determined values of $K_{\mathrm{s}}$ for the reactions can be used to ensure the best feeding strategy, with the purpose of achieving rapid growth and process stability. The variation in the kinetic parameters following enrichment time obtained in this study reflects variations in the purity of the biomass and changes to the environment in the reactor.

\section{Conclusion}

An evaluation of the three phases of the process - the anammox reaction, denitrification and the cell lysis - were conducted with kinetic simulations in the batch experiment. Based on a comparison of the results of the simulations and their correlation indexes, it was determined that the Luong and Hanlev models are the most suitable kinetic models. Anammox biomass taken from the bottom of the EGSB reactor has the highest $r_{\max }$ of $0.30 \mathrm{gN} \mathrm{gVSS}{ }^{-1} \mathrm{~d}^{-1}$ and $K_{\mathrm{s}}$ of $53.38 \mathrm{mg} \mathrm{NH}_{4}{ }^{+} \mathrm{N}$ $\mathrm{L}^{-1}\left(123.84 \mathrm{mg} \mathrm{TN} \mathrm{L}^{-1}\right.$ ), which was validated both in the models and experimentally. Compared with the EGSB-anammox 
biomass, significant variations were found in the SAA of the UASB-anammox biomass from the top to the bottom of the reactor, from 0.1 to $0.6 \mathrm{gN} \mathrm{gVSS}^{-1} \mathrm{~d}^{-1}$, and the removal efficiency of the whole system was lower. The simulated inhibition coefficients were approximately $920 \mathrm{mg}^{\mathrm{TN} \mathrm{L}^{-1}}$ both for the EGSB-anammox and the UASB-anammox process. The addition of a second feeding in the batch experiment resulted in an increase in the SAA, especially for the higher purity anammox biomass.

\section{Acknowledgements}

This work was supported by JSPS (Japan Society for the Promotion of Science) KAKENHI Grant-in-Aid for JSPS Fellowes (26.04044) and JSPS Bilateral joint research propjets with CAS (Chinese Academy of Science). The first author gratefully acknowledges support through the Japan Society for the Promotion of Science (JSPS) as postdoctoral support.

\section{References}

1 T. Lotti, R. Kleerebezem, C. Lubello and M. van Loosdrecht, Water Res., 2014, 60, 1-14.

2 M. Strous, J. G. Kuenen and M. S. M. Jetten, Appl. Environ. Microbiol., 1999, 65, 3248-3250.

3 C. J. Tang, P. Zheng, L. Y. Chai and X. B. Min, Int. Biodeterior. Biodegrad., 2013, 82, 141-148.

4 R. C. Jin, P. Zheng, A. H. Hu, Q. Mahmood, B. L. Hu and G. Jilani, Chem. Eng. J., 2008, 138, 224-230.

5 R. C. Jin, B. S. Xing, J. J. Yu, T. Y. Qin and S. X. Chen, Ecol. Eng., 2013, 53, 130-137.

6 A. A. V. deGraaf, P. deBruijn, L. A. Robertson, M. S. M. Jetten and J. G. Kuenen, Microbiology, 1996, 142, 2187-2196.

7 C. Trigo, J. L. Campos, J. M. Garrido and R. Mendez, J. Biotechnol., 2006, 126, 475-487.
8 M. Strous, J. J. Heijnen, J. G. Kuenen and M. S. M. Jetten, Appl. Microbiol. Biotechnol., 1998, 50, 589-596.

9 A. Dapena-Mora, J. L. Campos, A. Mosquera-Corral, M. S. M. Jetten and R. Mendez, J. Biotechnol., 2004, 110, 159-170.

10 J. J. Yang, J. Trela, M. Zubrowska-Sudol and E. Plaza, Ecol. Eng., 2015, 75, 413-420.

11 J. Haldane, GREEN AND CO, 1965, pp. 74-92.

12 V. H. Edwards, Biotechnol. Bioeng., 1970, 12, 679-712.

13 J. H. T. Luong, Biotechnol. Bioeng., 1985, 27, 280-285.

14 K. Han and O. Levenspiel, Biotechnol. Bioeng., 1988, 32, 430437.

15 S. Aiba and M. Nagatani, Biotechnol. Bioeng., 1968, 10, 845864.

16 T. T. Chen, P. Zheng, L. D. Shen, S. Ding and Q. Mahmood, J. Hazard. Mater., 2011, 190, 28-35.

17 E. I. P. Volcke, M. C. M. van Loosdrecht and P. A. Vanrolleghem, Water Sci. Technol., 2007, 56, 117-125.

18 I. Tsushima, Y. Ogasawara, T. Kindaichi, H. Satoh and S. Okabe, Water Res., 2007, 41, 1623-1634.

19 A. Dapena-Mora, S. W. H. van Hulle, J. L. Campos, R. Mendez, P. A. Vanrolleghem and M. Jetten, J Chem Technol Biot, 2004, 79, 1421-1428.

20 J. Zhang, L. F. Qiu and Y. M. Chen, Appl. Mech. Mater., 2013, 567-570.

21 S. Bagchi, R. Biswas and T. Nandy, J. Ind. Microbiol. Biotechnol., 2010, 37, 943-952.

22 H. Lopez, S. Puig, R. Ganigue, M. Ruscalleda, M. D. Balaguer and J. Colprim, J. Chem. Technol. Biotechnol., 2008, 83, 233241.

23 T. Wang, H. M. Zhang, F. L. Yang, S. T. Liu, Z. M. Fu and H. H. Chen, Bioresour. Technol., 2009, 100, 2501-2506.

24 Z. Li, X. Xu, X. Xu, F. Yang and S. Zhang, Chemosphere, 2014, 140, 106-113. 